\title{
Al-Mahali Islamic Boarding School Administration Empowerment through Financial Management in Conformity with Accounting Standards
}

\author{
Enok Rusmanah*, Amelia Rahmi, Fredi Andria, Jalaludin Almahali \\ Accounting Study Program, Pakuan University, J1 Pakuan, Bogor, Indonesia, 16143 \\ Correspondence: Enok Rusmanah (enok.rusmanah@unpak.ac.id)
}

Received: 6 December 2020 - Revised: 14 December 2020 - Accepted: 14 December 2020

\begin{abstract}
Islamic boarding schools have an important role in Indonesia not only in developing religious knowledge but also in the building of character for the nation. With 26,000 schools in 2018 and around 4 million students recorded, Islamic boarding schools are among one of the various institutions in Indonesia that partake in the field of education. Islamic boarding schools also have a role in the country's economic development. However, regarding financial management as an educational institution, many Islamic boarding schools still utilise manual record-keeping methods. Such methods are currently insufficient to facilitate institutional development. The Al-Mahali Islamic boarding school is well aware of this issue and took the initiative to invite speakers from Economics Faculty of Pakuan University to share their knowledge on financial record-keeping in conformity with financial accounting standards (PSAK 45, SAK ETAP, and SAKSyariah). The knowledge-sharing program was held in an SAK based accounting training activity for the financial administration of Al-Mahali Islamic boarding school and students in general as a provision to expand their knowledge. The program was carried out smoothly and was greeted with enthusiasm by the participants. A follow-up mentoring session was planned to be held in the future regarding the implementation of SAK.
\end{abstract}

Keywords: Islamic Boarding School, Financial Statement, Financial Accounting Standard

Citation Format: Rusmanah, E., Rahmi, A., Andria, F., \& Almahali, J. (2021). Al-Mahali Islamic Boarding School Administration Empowerment through Financial Management in Conformity with Accounting Standards. Journal of Community Practice and Social Welfare, 1(1), 33-47. 


\section{INTRODUCTION}

Islamic boarding schools have been a part of Indonesian society for hundreds of years. Through teaching Islamic religious studies, Islamic boarding schools have contributed to the development of societal welfare, especially in the field of religious education. Islamic boarding schools are not only religiously distinct but also have many unique characteristics influenced by local traditions and culture (Kompasiana.com, 2020).

In line with infrastructure development in Indonesia, religious studies learning activities, which were initially only carried out in the foyer of mosques, prayer rooms, and cleric's residences, have now grown, developed, and adapted to the demands of time to become educational institutions which are managed in a professional and modern manner. Islamic boarding schools have also experienced very significant growth in numbers over the last few decades in rural, suburban, and urban areas (Muhyiddin, 2017).

Until 2018 there were 26,000 Islamic boarding schools with approximately 4 million students in Indonesia (Faradisi, 2019). This number is spread across 34 provinces in Indonesia with several of them accommodating most schools, such as in Aceh, West Java, Central Java, East Java, and Banten. The following is data for Islamic boarding schools in five regions.

Table 1. Highest number of Islamic Boarding School (IBS) in five provinces

\begin{tabular}{rrrrrrr}
\hline \multirow{2}{*}{ No } & \multirow{2}{*}{ Province } & IBS & \multicolumn{2}{c}{ IBS type } & \multicolumn{2}{c}{$\begin{array}{c}\text { Number of students in } \\
\text { IBS }\end{array}$} \\
\cline { 4 - 8 } & & $\begin{array}{c}\text { Educational } \\
\text { units }\end{array}$ & $\begin{array}{c}\text { Educational unit } \\
\text { administrators }\end{array}$ & Live in IBS & $\begin{array}{c}\text { Not living } \\
\text { in IBS }\end{array}$ \\
\hline 1 & Aceh & 1.177 & 795 & 382 & 124.532 & 51.432 \\
2 & West Jawa & 8.343 & 5.465 & 2.878 & 147.467 & 306.667 \\
3 & Central Jawa & 3.787 & 1.992 & 1.795 & 166.605 & 132.269 \\
4 & East Jawa & 4.452 & 794 & 3.658 & 323.293 & 241.006 \\
5 & Banten & 4.578 & 2.883 & 1.695 & 60.897 & 96.061 \\
\hline & Total & 22.337 & 11.929 & 10.408 & 822.794 & 827.435
\end{tabular}

Source: Ditpdpontren.kemenag.go.id, data processed in 2020.

Islamic boarding schools, according to the Minister of Religion Regulation No.3, 1979, are classified into four types (Sulistiani, 2019a): 


\section{School type A}

In this type of Islamic boarding school, students study and live in a boarding school environment with the teaching process taking place traditionally (wetonan or sorogan).

2. School type B

This type of Islamic boarding school organizes teaching processes classically and the teachings by clerics are directly applied, given at pre-determined times. Students live in boarding school dormitories.

\section{School type C}

This Islamic boarding school is just a dormitory where the students would study externally (madrasah or other public schools). The Clerics only supervises and guides the students.

\section{School type D}

An Islamic boarding school system which is organized with school and madrasah systems.

Based on the latest research conducted by Balitbang of the Ministry of Religion, by considering aspects such as institutional status, governance, implementation of educational programs, expansion of managed fields, peculiarities of scientific fields, diversification of economic enterprises and networks and other funding connections, Islamic boarding schools are grouped into several classifications, namely Islamic boarding schools that are characteristically institutional, scientific, and organized (Singorejo, 2018). Institutionally, the schools are further grouped into six:

1. Modern and traditional

2. Salafist and khalafist

3. Basic, moderate, and advanced

4. Small, medium, and large

5. For children, students and parents

6. Rural and urban.

From these changes in classifications, it can be observed that over time, the institutional structure of Islamic boarding schools has expanded. They no longer only teach religious studies, but also general studies and technologies (Suherman, 2019). The modernisation of Islamic boarding schools has resulted in a compounding of complexity in many of their activities which resulted in the demand for adequate management per the needs of institutional structures. In effect, many schools are 
managed by forming Islamic foundations. Islamic boarding schools have also been known to partake in business ventures to support boarding activities. These changes, of course, have an impact on various management elements which adapts according to the requisites. One of the elements affected by the organizational change is financial management.

Previous Islamic boarding school financial management was generally carried out through traditional and simple book-keeping methods, namely by pen-on-paper income and expenditure recording techniques (Niati et al., 2019). It was then further developed into centralized management through foundations. With the need for organizational structure changes following increasingly complex operations and demands from interested parties regarding financial reports accountability, the schools are pushed to conform their financial reporting methods under a standard that stakeholders can accept (Sulistiani, 2019b).

One of the solutions offered came from a professional association (Ikatan Akuntan Indonesia/IAI), namely by establishing a standard that is applicable for Islamic boarding schools. In collaboration with IAI, Bank Indonesia had prepared a guidebook for the practice of Islamic boarding school accounting (IAI and Bank Indonesia, 2018). This guideline has been the benchmark for financial report making which is expected to meet the data needs of financial statement users and provide the framework for financial reports to achieve uniformity and acquire comparative level (Suherman, 2019).

Al-Mahali Islamic boarding school is located on Raya Puncak Avenue KM 77 Bhima Chakti, Kp Muara RT 04/05, Kopo Village, Cisarua District, Bogor Regency, 16750, Tlp (0251) 2281911, and was founded by KH. Rafe'I bin Mama H Sadian in 1975. Over time, the boarding school developed and changed its name to Auladul Mahali Foundation to address community needs and accommodate the terms of quality and quantity. Up until now, the Auladul Al-Mahali Foundation has been organizing formal education for junior and senior high school levels. The school's teaching staffs consists of Ustadzs, Ustadzahs, and administrators from graduates of Religious and Public Universities and Islamic Boarding Schools.

The Auladul Mahali Foundation is an Islamic educational institution that has the form and spirit of an Islamic boarding school. It operates under spiritual values and is not affiliated with political and non-political groups or organizations. The foundation has 
distinguishable characteristics with unique traditions which are distinct from other formal institutions.

This distinction is not only concerning the method of education but includes other principal systems and patterns. The existence of the Auladul Mahali foundation amid society, especially Cisarua sub-district, Bogor, contributes as a medium for education and Islamic $d a^{\prime}$ wah as well as to the intellectual life of the nation's young generation in accordance with the 1945 Constitution.

The school's mission is to improve people's lives through preaching and education in an integrated and balanced manner. The school's motto is: Educate your children as they will live in an era that is not yours. The following is the profile of the Chairman of the Auladul Al-Mahali Foundation.

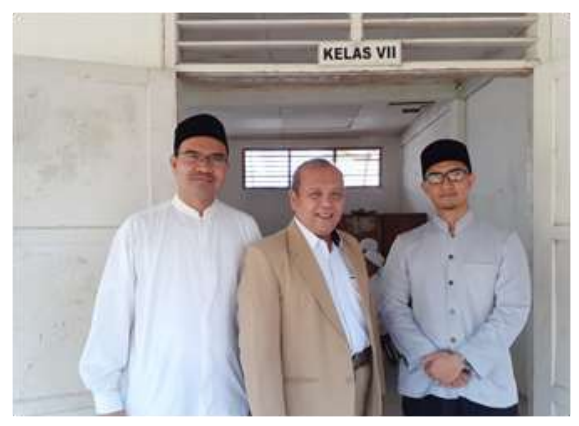

Figure 1. Profile of the Chairman of Auladul Al-Mahali Foundation

\section{PROBLEMS}

Following the discussions and interviews with the board of the school chaired by $\mathrm{Mr}$ Jalaludin Almahali, it can be concluded that, at present, the schools are facing the following problems:

1. The school's finances are managed through simple book-keeping, which only records income and expenditure.

2. The school's managers have not yet developed skills on the basics of general accounting.

3. The school's managers do not yet have further insight regarding the recording of Islamic boarding school accounting-based financial reports in accordance with Statement of Financial Accounting Standards 45 (PSAK 45), Financial Accounting Standards for Entities without Public Accountability (SAK ETAP), and Shariah Financial Accounting Standards (SAKSyariah). 
Therefore, the solution offered by the community service team regarding the problems faced by the Al-Mahali Islamic boarding school is to hold outreach activities in line with the following objectives:

\section{Transfer of fundamental knowledge on financial management system}

This session was held to provide insight into financial management and show the importance of financial management within an organizational entity. This knowledge sharing session was applied in the form of mentoring on the topic of financial management in organizations to provide the school's managers with some basic insights.

\section{Transfer of accounting basics knowledge}

The activity then focused on discussions regarding the introduction of accounting basics. This knowledge is useful as a basis for providing managers with some insights regarding modern financial recording. Knowledge of accounting-based recording is important considering that simple book-keeping, which only recognizes income and expenditure, is no longer sufficient for developed institutions with modern management.

\section{Transfer of special accounting knowledge}

After the presentation of basic accounting, the discussion continued with an introduction to Islamic boarding school accounting. Islamic boarding school accounting, when compared to basic accounting, generally has distinguishing aspects, namely a financial accounting standard that references the PSAK 45, which is specifically for the presentation of non-profit organisation accounting. It also refers to SAK ETAP, which is a special financial accounting standard for entities without public accountability and Syariah financial accounting standards.

With the identification of problems faced by the Al-Mahali Islamic boarding school, it is hoped that sharing knowledge through mentoring can provide insights to the managers and students regarding the demands of modern financial recording because book-keeping, which only involves simple income and expenditure records, are no longer sufficient when juxtaposed with an increasingly complex development of institutions.

The management of the Al-Mahali Islamic boarding school was conscious of these issues and took the initiative to hold outreach activities for its managers regarding financial accounting. The activities were then carried out in collaboration with a community service team from the Faculty of Economics, Pakuan University. 
The service team not only explained the importance of financial management and financial reporting for Islamic boarding schools based on Indonesian Financial Accounting Standards but also took part in a series of other seminars, namely seminars on entrepreneurship. In the end, the decision to implement this SAK is in the hands of policy and decision-makers within the management of the Al-Mahali Islamic boarding school because there are no laws that compel Islamic boarding schools to apply this financial accounting standard (Romli, 2019).

\section{IMPLEMENTATION METHOD}

The implementation method is through knowledge-sharing carried out by providing mentoring to participants, particularly the school principals, treasurers or financial managers of Islamic boarding schools as well as some students. This activity was carried out beginning with community service preparation and planning for activity follow-up. The following are the stages of preparation for Islamic boarding school accounting mentoring activities carried out by the community service team:

\section{Preparation}

Representatives from the team coordinated with the Chairperson of the Auladul A1Mahali Foundation in Cisarua after being contacted through Mr Jalaludin as the head of the boarding school management foundation to carry out the knowledge-sharing of Islamic boarding school accounting. Through the discussion, the schedule for survey and mentoring was determined.

\section{Survey/Discussion}

After discussions with all members of the community service team regarding the results of the meeting with Pak Jalaludin, the Chairperson of the Auladul Al-Mahali Foundation, the service team decided to conduct an initial survey to the school and discuss as well as follow up on the implementation of financial report mentoring, including exploration on any topics contained in the mentoring material form that's relevant to the needs and problems faced by the foundation.

\section{Mentoring Activity}

The activity was carried out in the Al-Mahali Islamic Boarding School Hall for 1 (one) day divided into three sessions, namely session 1 at $08.00-10.00$ and session 2 at $10.00-12.00$. Then the third session and discussion took place from $13.00-16.00$. 


\section{Follow-Up}

The follow-up of this activity was carried out with the aim of observing the extent of the participants' ability to understand the material that had been presented, and to confirm the possibility of implementing an Islamic boarding school accounting system and the readiness of the board of Al-Mahali School.

Afterwards, the methods of implementing outreach activities were explained in more detail by community service providers to deliver more insights into financial management based on Islamic school accounting in conformity with PSAK 45, SAK ETAP, and SAKSyariah. The steps taken in this service activity after conducting surveys and interviews with the board of the Al-Mahali Islamic Boarding School are as follows:

\section{Training in the form of mentoring on Islamic boarding school accounting system}

This activity was carried out in the Al-Mahali boarding school hall. In this method, the counsel providers divide the session into three with the first session delivering materials related to organizational financial management, followed by the provision of knowledge that delivers insights on the basics of general accounting to managers and students as an introduction to Islamic boarding school accounting material. After the materials were delivered, the mentoring then continues to the third session by delivering materials on the special characteristics of Islamic boarding school accounting which is related to foundation accounting that requires distinct treatments (Lubis and Ovami, 2019). These topics were given with the hope of providing knowledge and as the basics for future applications.

\section{Discussion session}

The Discussion Session was held in the Al Mahali Islamic Boarding School Hall as well and was still attended by the head of the foundation, school principals, treasurers, and the school's financial managers. This discussion method aims to identify the obstacles and problems faced by the school relating to the recording and preparations of financial reports. After they were identified, the managers can hopefully determine the necessary steps to take regarding the possibility of consistent step by step application of Islamic boarding school accounting within the financial management of the institution.

\section{Follow-up}

This activity was held in response to and to follow up on the application of Islamic boarding school accounting by providing examples of organisational financial reports 
consisting of financial position reports, activity reports, cash flow reports and notes on financial statements. The hope is that the school's administration can emulate these examples.

\section{RESULTS AND DISCUSSION}

Several studies on the application of Islamic boarding school accounting have found that the Islamic boarding school accounting system has not been optimally implemented by local Islamic boarding schools (Suherman, 2019, Lubis and Ovami, 2019, Niati, et al., 2019, Sulistiani, 2019b). Meanwhile, Islamic boarding schools have developed in such a way as to meet the challenges modern demands such as accountable financial reports because today's boarding schools have a role and responsibility towards not only internal parties but also external parties such as the general public (Sulistiani, 2019a).

Research by Murdayanti and Puruwita's (2019), with a research sample of six Islamic boarding schools in JABODETABEK and 116 respondents consisting of employees, found that human resource competence has a positive effect on the accountability of the schools. Therefore, the Chairman of the Auladul Al-Mahali Foundation took the initiative to share knowledge through mentoring which was held in the Al-Mahali Islamic Boarding School Hall.

This was done specifically to provide insights for the school's administrators. Because, in line with the research conducted by Rachmani (2020) on ten Islamic boarding schools in Pekalongan Regency, it shows that the knowledge possessed by the school's managers will relate to the presentation of Islamic boarding school financial reports. The following is a documentation of the initial survey and the handover of the collaboration certificate between the community service team and the Chairman of the Auladul AlMahali Foundation.
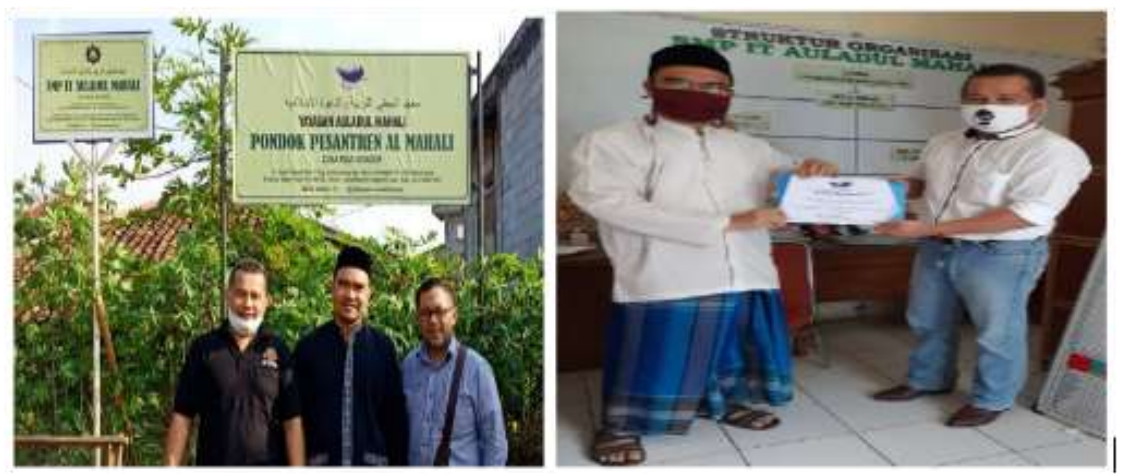

Figure 2. Initial survey and handover of cooperation certificate 
Community Service Activities at the Al-Mahali Islamic Boarding School in the form of mentoring, lectures and discussions were held on Thursday, September third, 2020, with participants from the boarding school's management and several students. The problem faced by Islamic boarding schools so far is the lack of understanding that, in preparing the financial statements of the foundation, there are certain rules that must be followed if they intend to manage them in a modern way and in accordance with applicable accounting standards to increase the accountability of financial statements. To provide solutions to these problems, training was held in the form of mentoring, starting from organizational financial planning, the basics of accounting and non-profit accounting specifically for organizations that are structured as foundations. The following is the mentoring material and documentation of the mentoring initiation:

Table 2. Islamic boarding school accounting mentoring materials at Al-Mahali Islamic Boarding

School

\begin{tabular}{ccc}
\hline No. & Session & Material \\
\hline 1 & First & Importance of financial management \\
2 & Second & Basic accounting \\
3 & Third & Islamic Boarding School Accounting (PSAK 45, SAK ETAP, \\
& & SAKSyariah) \\
4 & Discussion & Sharing, questions and answers \\
\hline
\end{tabular}

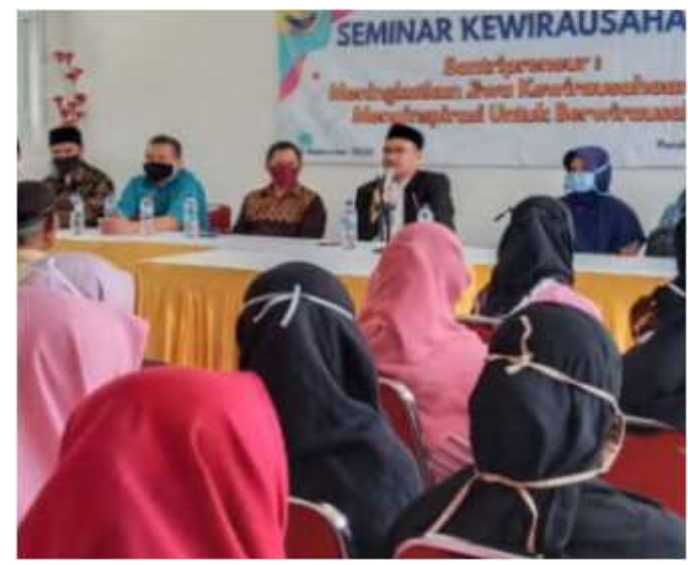

Figure 3. Opening of mentoring activity

The results of the community service activities at the Al-Mahali Islamic Boarding School are as follows: 


\section{Transfer of fundamentals of financial management system}

The implementation of activities begins by providing knowledge on good financial management for businesses and non-profit organizations such as Islamic boarding schools and foundations. The results of this activity provided the participants with the insight that an organization cannot effectively run without good financial management. For an organization to survive long-term, (going concern concept) it must be supported by good management, one of which is through good financial management. Likewise, modern financial management must provide clear information on the separation or relationship between owner and manager (entity concept).

\section{Transfer of accounting basics}

After providing knowledge on the importance of financial reporting, the next step is to introduce the basics of accounting. This knowledge is deliberately given in advance considering that the subject of accounting is still considered new in the AlMahali Islamic boarding school. It is important to introduce basic accounting so that participants understand how the basics of accounting should be done when referring to accounting equations. The result was that participants showed interest in learning more about accounting, even when the discussion and question and answer sessions had not yet started. Some participants actively expressed their curiosity by asking and consulting.

\section{Transfer of special accounting knowledge to Islamic boarding schools}

This session was specifically intended for the board of the Al-Mahali school, but because some of the students showed interest, this session was not only attended by administrators like the previous sessions but also by several students. The material presented in this session was more focused on the management of Islamic boarding school accounting. Because these schools, as well as foundations that manage Islamic boarding schools, are intended to be non-profit and as a public service, the accounting applied also adjusts to the special accounting treatment for non-profits, namely using PSAK 45, SAK ETAP, and SAKSyariah as guidelines. In this session, it was introduced how, for example, institutional assets are bound either temporarily or permanently. Regarding the treatment of waqf, the result shows that management was not only interested in knowing more but also had the intention to apply it in their financial management activities. The managing chairman submitted 
a request for similar events to be held again in the future and for community service providers to accompany its implementation.
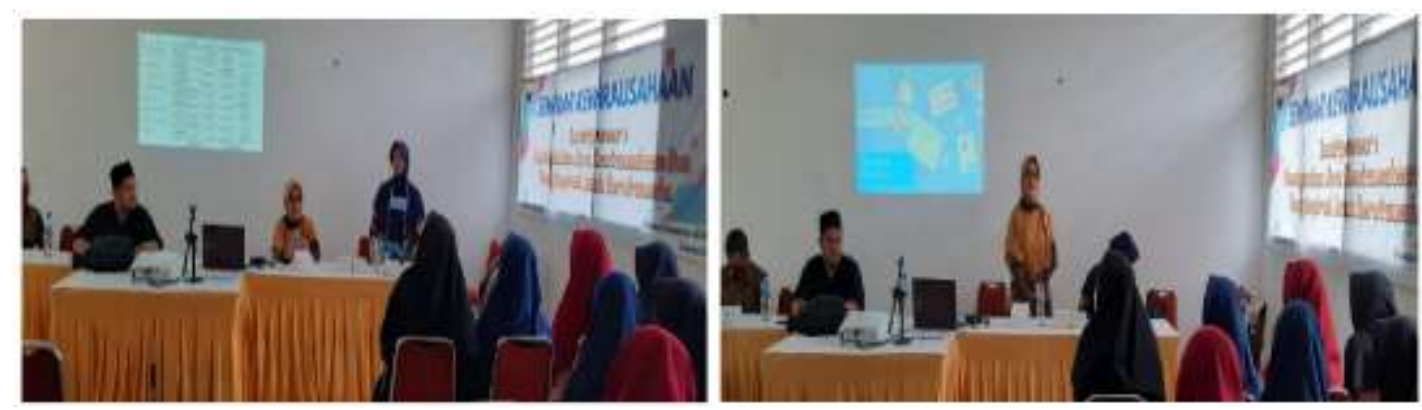

Figure 4. Basic accounting and Islamic Boarding school accounting mentoring activities

Overall, knowledge sharing activities through mentoring on Islamic boarding school accounting have been going well. Participants are enthusiastic about the information delivered by the service team. Even after this mentoring session, the school's manager proposed another similar activity to be held as a follow-up, especially concerning assistance in the application of Islamic boarding school accounting. The hope is that in the future, Al-Mahali Islamic boarding school will have adequate accounting data and be able to keep up with the times, in line with the research of Suharni and Sari (2019) that a good accounting information system will be able to support higher-quality decision making in line with the changing times.

\section{CONCLUSION}

Islamic boarding schools are identified as a place for religious studies. However, these schools have expanded their scope into various other subjects. Other general fields of study have also been provided. Thus, the management needs for Islamic boarding schools that had attained a more complex level of operations are also adjusted to include financial management. Islamic boarding school accounting provides an answer to this challenge by establishing a standard that can standardise the formats these school's financial reports. AlMahali Islamic boarding school is also aware of this challenge. Along with the demands of the times and technology, the school took the initiative to accommodate mentoring sessions regarding knowledge-sharing of Islamic boarding school accounting system. Through collaboration with the community service team of the Faculty of Economics, Pakuan University, mentoring on Islamic boarding school financial reporting went well and smoothly and even led to enthusiasm for the implementation of Islamic boarding 
school accounting based on PSAK 45, ETAP, and SAKSyariah. The school's managers also hoped that there will be further assistance to follow-up on the results of this outreach activity. As the old saying goes, there is no ivory without cracks, and this program is no different. There are several shortcomings and obstacles faced during its implementation. Careful planning is suggested for future activities and monitoring and evaluation forms can also be utilised to determine whether the implementation of the Islamic boarding school accounting system is optimal.

\section{ACKNOWLEDGEMENT}

With the completion of this article, the community service team would like to thank Al-Mahali Islamic Boarding School for the opportunity to carry out community service for lecturers from the Faculty of Economics, Pakuan University at the Al-Mahali Islamic boarding school. The community service team would also like to thank all of the teams involved in the completion of this Community Service (PKM). Additionally, all activities were carried out with health protocols in mind.

\section{REFERENCES}

Ikatan Akuntan Indonesia dan Bank Indonesia. (2018). Pedoman Akuntansi Pesantren, Bank Indonesia.

Faradisi J., Roghiebah. (2019). Pedoman Akuntansi Pesantren IAI sebagai Jawaban Atas Urgensi Pencatatan Keuangan Pondok Pesantren, http://mgt.unida.gontor.ac.id/pedoman-akuntansi-pesantren-iai-sebagai-jawaban-atasurgensi-pencatatan-keuangan-pondok-pesantren/, retrieved on 27 September 2020.

Kompasiana.com. (2020). Sejarah Singkat Pesantren, https:/www.kompasiana.com/asaikanaasai9565/5e8612c7097f36142755eb73/sejarahsingkat-pesantren-kompasiana-com?page=all\#section1, retrieved on 25 September 2020 .

Lubis, F.N. \& Ovami, D.C. (2019). Analisis Penyusunan Laporan Keuangan Berdasarkan Pernyataan Standar Akuntansi Keuangan (PSAK) No. 45 (Studi Kasus: Yayasan Pesantren Al-Husna). Prosiding Seminar Nasional dan Expo II Hasil Penelitian dan Pengabdian Masyarakat.

Muhyiddin. (2017). Pertumbuhan Pesantren di Indonesia Dinilai Menakjubkan, https://www.republika.co.id/berita/dunia-islam/islam-nusantara/17/11/30/p0881k396pertumbuhan-pesantren-di-indonesia-dinilai-menakjubkan, retrieved on 21 September 2020. 
Murdayanti, Y. \& Puruwita, D. (2019). Kompetensi SDM Keuangan dan Akuntabilitas Keuangan Pesantren. Jurnal Akuntansi, Ekonomi, dan Manajemen Bisnis, 7(1), 1929. https://doi.org/10.30871/jaemb.v7i1.1085

Niati, et al. (2019). Pelatihan Pengelolaan Manajemen Keuangan dan Pelaporan Keuangan Akuntansi Pesantren Bagi Pengelola Yayasan Pondok Pesantren X di Kota Semarang. Jurnal Surya Masyarakat, 2(1), 76-79.

Pangkalan Data Pondok Pesantren. (2019). Statistik Data Pondok Pesantren, Kemenag. https://ditpdpontren.kemenag.go.id/pdpp/statistik, retrieved on 21 September 2020.

Rachmani, F.A. (2020), Pengaruh Pengetahuan tentang Pedoman Akuntansi Pesantren terhadap Penyajian Laporan Keuangan Pesantren. Proceeding of National Conference of Accounting and Finance, 2, $39-46$.

Romli, M. (2018). Peluang dan Tantangan Penerapan Sistem Akuntansi Pesantren Indonesia (SANTRI) di Indonesia, Ekomadania, 2(1), 35 - 51.

Singorejo, I. (2018). Klasifikasi Pondok Pesantren Berdasarkan Penelitian Balitbang Kementerian Agama, https://pontren.com/2018/01/28/klasifikasi-pondok-pesantrenberdasarkan-penelitian-balitbang-kementerian-agama/, retrieved on 21 September 2020.

Suharni, S. \& Sari, S.R.K. (2019). Penerapan Sistem Informasi Akuntansi pada Pondok Pesantren di Kota Madiun, Ekomaks: Jurnal Ilmu Ekonomi, Manajemen, dan Akuntansi, $8(2), 53-63$.

Suherman, L.P. (2019). Analisis Pentingnya Akunatansi Pesantren: Studi Pada Pondok Pesantren Al-Matuq Sukabumi. Jati: Jurnal Akuntansi Terapan Indonesia, 2(2), 65-70.

Sulistiani, D. (2019a). Akuntansi Pondok Pesantren dalam Meningkatkan Akuntabilitas Publik. Prosiding Seminar Nasional Akuntansi, Manajemen, dan Keuangan, 1(1), 1-10

Sulistiani, D. (2019b). Peningkatan Akuntabilitas Publik Melalui Sistem Informasi Akuntansi pada Pondok Pesantren Salafiyah. Akuntabilitas: Jurnal Ilmu Akuntansi, 12(2), $237-248$.

(C) 2021 by authors. Content on this article is licensed under a Creative Commons Attribution 4.0 International license. (http://creativecommons.org/licenses/by/4.0/). 


\section{Original Title:}

Pemberdayaan Pengurus Pesantren Al-Mahali Melalui Pengelolaan Keuangan Berbasis Standar Akuntansi

Abstrak. Pesantren memiliki peran penting di Indonesia tidak hanya dalam mengembangkan ilmu keagamaan tetapi juga dalam pembangunan karakter bangsa. Dengan jumlah mencapai 26.000 pondok di tahun 2018, dan santri sekitar 4 juta jiwa, pesantren di Indonesia menjadi salah satu lembaga pendidikan yang turut berperan serta dalam pendidikan. Bahkan, pada perkembangannya pesantren juga memiliki peran dalam pembangunan perekonomian. Tetapi dalam pengelolaan keuangannya sebagai lembaga pendidikan, masih banyak pesantren yang mengelola keuangannya dengan pencatatan yang sederhana. Sehingga kondisi ini tidak lagi memadai untuk memfasilitasi perkembangan lembaga. Pesantren Al-Mahali sangat menyadari akan tantangan ini. Sehingga pesantren Al-Mahali berinisiatif untuk menyelenggarakan sharing ilmu mengenai pencatatan keuangan yang berbasis standar akuntansi keuangan (PSAK 45, SAK ETAP, dan SAKSyariah) bekerjasama dengan Fakultas Ekonomi, Universitas Pakuan. Sharing ilmu ini diselenggarakan dalam sebuah kegiatan pelatihan akuntansi berbasis SAK untuk para pengelola keuangan pesantren Al-Mahali dan para santri umumnya sebagai bekal untuk membuka wawasan mereka. Hasilnya pelatihan terlaksana dengan baik dan lancar serta disambut dengan semangat oleh seluruh warga pesantren. Bahkan ke depan direncanakan akan diselenggarakan sesi pendampingan dalam penerapan SAK sebagai tindak lanjut dari kegiatan ini.

Kata kunci: Pesantren, laporan keuangan, Standar Akuntansi Keuangan 